\title{
Current Advances on Virus Discovery and Diagnostic Role of Viral Metagenomics in Aquatic Organisms
}

\author{
Hetron M. Munang'andu ${ }^{1 *}$, Kizito K. Mugimba ${ }^{1,2}$, Denis K. Byarugaba ${ }^{2}$, Stephen Mutoloki ${ }^{1}$ \\ and Øystein Evensen ${ }^{1}$
}

${ }^{1}$ Section of Aquatic Medicine and Nutrition, Department of Basic Sciences and Aquatic Medicine, Faculty of Veterinary Medicine and Biosciences, Norwegian University of Life Sciences, Oslo, Norway, ${ }^{2}$ Department of Biotechnical and Diagnostic

Sciences, College of Veterinary Medicine, Animal Resources and Biosecurity, Makerere University, Kampala, Uganda

\section{OPEN ACCESS}

Edited by:

Jean-Christophe Avarre, Institut de Recherche pour le

Développement, France

Reviewed by:

Stéphan Jacquet,

Institut National de la Recherche

Agronomique (INRA), France

Alberto Cuesta,

University of Murcia, Spain

*Correspondence:

Hetron M. Munang'andu hetroney.mweemba.munangandu@ nmbu.no

Specialty section

This article was submitted to

Aquatic Microbiology,

a section of the journal

Frontiers in Microbiology

Received: 23 August 2016

Accepted: 27 February 2017

Published: 22 March 2017

Citation:

Munang'andu HM, Mugimba KK

Byarugaba DK, Mutoloki S and

Evensen Ø (2017) Current Advances

on Virus Discovery and Diagnostic

Role of Viral Metagenomics in Aquatic

Organisms. Front. Microbiol. 8:406.

doi: 10.3389/fmicb.2017.00406
The global expansion of the aquaculture industry has brought with it a corresponding increase of novel viruses infecting different aquatic organisms. These emerging viral pathogens have proved to be a challenge to the use of traditional cell-cultures and immunoassays for identification of new viruses especially in situations where the novel viruses are unculturable and no antibodies exist for their identification. Viral metagenomics has the potential to identify novel viruses without prior knowledge of their genomic sequence data and may provide a solution for the study of unculturable viruses. This review provides a synopsis on the contribution of viral metagenomics to the discovery of viruses infecting different aquatic organisms as well as its potential role in viral diagnostics. High throughput Next Generation sequencing (NGS) and library construction used in metagenomic projects have simplified the task of generating complete viral genomes unlike the challenge faced in traditional methods that use multiple primers targeted at different segments and VPs to generate the entire genome of a novel virus. In terms of diagnostics, studies carried out this far show that viral metagenomics has the potential to serve as a multifaceted tool able to study and identify etiological agents of single infections, co-infections, tissue tropism, profiling viral infections of different aquatic organisms, epidemiological monitoring of disease prevalence, evolutionary phylogenetic analyses, and the study of genomic diversity in quasispecies viruses. With sequencing technologies and bioinformatics analytical tools becoming cheaper and easier, we anticipate that metagenomics will soon become a routine tool for the discovery, study, and identification of novel pathogens including viruses to enable timely disease control for emerging diseases in aquaculture.

Keywords: aquatic organisms, diagnosis, discovery, etiology, novel, viral metagenomics, viruses

\section{INTRODUCTION}

Traditionally, the diagnosis of viral diseases has been dependent on cell culture in which viruses exhibit cytopathic effects (CPE) and immunoassays based on antibodies having the binding specificity for the virus to be diagnosed (Leland and Ginocchio, 2007) in addition to amplification of specific gene segments of the viruses by polymerase chain reaction (PCR). Virus propagation using cell-culture has significantly contributed to the development of protective vaccines against 
fish diseases such as infectious pancreatic necrosis virus (IPNV), viral hemorrhagic septicemia virus (VHSV), infectious hematopoietic necrosis virus (IHNV), salmonid alphavirus (SAV), and infectious salmon anemic virus (ISAV) in aquaculture (Sommerset et al., 2005; Gomez-Casado et al., 2011; Munang'andu et al., 2014a,b; Munang'andu and Evensen, 2015). However, the bulk of viruses found in aquatic environments are unculturable (Wang et al., 2002) and there are no antibodies available for their identification nor specific primers for PCR detection, which precludes their study. The detection of nonculturable viruses (Handelsman, 2004; Schloss and Handelsman, 2005), by molecular biology based tools such as the PCR test demand that the genomic sequence of the target virus be known prior to diagnosis (Yamaguchi et al., 2000; Bibby, 2013), which precludes the identification of novel viruses whose sequences are unknown (Gao and Moore, 1996). Given that aquaculture is continuously faced with the challenge of identifying novel pathogenic viruses infecting different fish, crustaceans, and shellfish species, there is an urgent need to develop diagnostic tools able to identify those viruses in order to expedite the process of developing timely disease control strategies.

In the last decade, high throughput next generation sequencing (NGS), has emerged not only as a powerful tool able to enhance our understanding of the host response to infection (Xu et al., 2015, 2016a,b), but as a tool able to unravel a large number of viral genomes using metagenomics analysis (Handelsman, 2004; Riesenfeld et al., 2004). Viral metagenomics analysis is a culture independent approach that does not require prior knowledge of the genomic sequence of the virus to be identified (Handelsman et al., 1998; Streit and Schmitz, 2004; Gross et al., 2010; Mokili et al., 2012; Martínez-Porchas and Vargas-Albores, 2015). It provides a unique opportunity able to identify several viruses in one sample at the same time. The scope of its application in aquaculture is bound to expand from the analysis of environmental microbial composition to the search for novel viruses, routine diagnosis, disease surveillance, and public health. Given the increase of emerging pathogenic viruses in aquaculture, it is anticipated that viral metagenomics is bound to expedite the process of identifying novel viruses that infect different aquatic organisms before they cause disease outbreaks reaching epidemic proportions. The number of viral metagenomics studies has exponentially increased from $<10$ publications in 2002, when this technology was first discovered (Handelsman, 2004; Riesenfeld et al., 2004), to $>300$ publications by 2010 (Mokili et al., 2012). Although its application in environmental studies has been widely reviewed by different scientists (Fuhrman, 1999; Breitbart et al., 2002; Edwards and Rohwer, 2005), there are limited reviews on its application in the discovery of novel viruses in aquaculture.

Hence, in this review we first provide a historical background of viral diseases discovered using the traditional cell culture, immunoassays, and basic PCR techniques in aquaculture. As a second step, we provide an overview of viral diseases discovered using viral metagenomics and NGS in order to compare the traditional approaches and viral metagenomics analysis in the discovery of novel viruses. In addition, we also highlight the diagnostic role and other potential uses of viral metagenomics apart from its use in the discovery of novel viruses. Based on observations herein, we advocate that scientists faced with the challenge of identifying new viruses infecting aquatic organisms should explore its application in order to expedite the process of developing timely disease control strategies for emerging viral diseases for aquatic organisms.

\section{HISTORICAL PERSPECTIVES OF VIRAL DISEASES IN AQUACULTURE}

The major viral diseases of aquatic organisms can be divided into viruses of finfish, crustaceans, and marine mammals as shown below.

\section{Viral Diseases of Finfish}

The major challenge in the control of viral diseases in aquaculture is the long duration it takes from the first time the disease is discovered through clinical reports to identification of the etiological agent. This delay precludes our ability to develop timely disease control strategies. For example, IPNV was first reported as a clinical disease causing acute catarrhal enteritis in salmonids in 1940 (McGonigle, 1941) and yet the virus was first identified and characterized 20 years later in 1960 (Wolf et al., 1960). VHSV was first identified in 1962 (Jensen, 1965) followed by IHNV in 1969 (Wingfield et al., 1969) although reports of mortalities caused by both viruses date far back in the early 1950s. In the case of nodavirus, infections causing major problems in hatcheries as well as clinical signs linked to lethargy, anorexia, pale coloration and corkscrew swimming in barramundi (Lates calcarifer) and other fish species in Asia were first reported in the 1970 s and yet the virus was first characterized in 1990 (Glazebrook et al., 1990; Munday et al., 2002). SAV was first reported as a disease causing skeletal muscle and cardiac myopathy in salmonids in 1976 and yet the virus was first identified and characterized almost two decades later in 1995 (Boucher et al., 1994; Castric et al., 1997). Outbreaks of cardiomyopathy syndrome (CMS) were first reported in 1985 (Amin and Trasti, 1988) while the virus responsible for the disease was recently characterized as piscine myocarditis syndrome virus (PMCV) in 2011 (Haugland et al., 2011). Similarly, heart and skeletal muscle inflammation (HSMI) outbreaks were first reported in 1999 (Kongtorp et al., 2004a,b) and yet the etiological agent was recently identified after a decade as piscine reovirus (PRV) now referred to as piscint orthoreovirus (Løvoll et al., 2010; Palacios et al., 2010). Table 1 shows a summary of the major fish viral diseases showing the year when clinical cases were first reported and the year when the etiological agent was identified. The general trend is that etiological agents were only identified after they caused disease outbreaks reaching epidemics proportions, which is in line with observations made by Alavandi and Poornima (2012) who pointed out that our response to viral infection has mainly been reactive in the sense that a new pathogen is usually not identified until it has reached epidemic proportions. Hence, there is need to develop proactive diagnostic tools able to identify novel viruses before they cause disease outbreaks leading to high economic losses in aquaculture. 
TABLE 1 | Viruses infecting finfish discovered using traditional cell culture methods.

\begin{tabular}{|c|c|c|c|c|c|c|}
\hline \multirow[t]{2}{*}{ Virus } & \multirow[t]{2}{*}{ Family } & \multirow[t]{2}{*}{ Nucleic acid } & \multicolumn{2}{|c|}{ Clinical signs first reported } & \multicolumn{2}{|c|}{$\begin{array}{l}\text { Etiological virus identified and } \\
\text { characterized }\end{array}$} \\
\hline & & & Year & References & Year* & References \\
\hline \multicolumn{7}{|l|}{ A: VIRUSES INFECTING FINFISH } \\
\hline Infectious pancreatic necrosis virus & Birnaviridae & dsRNA & 1940 & McGonigle, 1941 & 1960 & Wolf et al., 1960 \\
\hline Viral hemorrhagic septicemia virus & Rhabdoviridae & $(-)$ ssRNA & $1950 s$ & Jensen, 1965 & 1962 & Jensen, 1965 \\
\hline Infectious hematopoietic necrosis virus & Rhabdoviridae & $(-) \operatorname{ssRNA}$ & 1950s & Rucker et al., 1953 & 1969 & Wingfield et al., 1969 \\
\hline Nervous necrosis virus & Nodaviridae & $(+)$ ssRNA & 1970 s & MacKinnon, 1987 & 1990 & $\begin{array}{l}\text { Glazebrook et al., 1990; Mori et al., } \\
1992\end{array}$ \\
\hline Salmonid alphavirus & Togaviridae & $(+)$ ssRNA & 1976 & Munro et al., 1984 & 1995 & $\begin{array}{l}\text { Boucher et al., 1994; Castric et al., } \\
1997\end{array}$ \\
\hline Infectious salmon anemia virus & Orthomyxoviridae & $(-)$ ssRNA & 1984 & Thorud and Djupvik, 1988 & 1995 & $\begin{array}{l}\text { Dannevig et al., 1995; Mjaaland et al., } \\
1997\end{array}$ \\
\hline Hirame rhabdovirus & Rhabdoviridae & $(-)$ ssRNA & 1984 & Kimura et al., 1986 & 1984 & Kimura et al., 1986 \\
\hline Piscine myocarditis syndrome virus & Totiviridae & dsRNA & 1985 & Amin and Trasti, 1988 & 2010 & $\begin{array}{l}\text { Løvoll et al., 2010; Haugland et al., } \\
2011\end{array}$ \\
\hline Epizootic hematopoietic necrosis virus & Iridoviridae & dsDNA & 1985 & Langdon et al., 1986 & 1985 & Langdon et al., 1986 \\
\hline Spring viremia of carp virus & Rhabdoviridae & $(-)$ ssRNA & 2002 & Dikkeboom et al., 2004 & 2002 & Dikkeboom et al., 2004 \\
\hline Tilapia lake virus & Orthomyxoviridae & $(-)$ ssRNA & 2009 & Eyngor et al., 2014 & 2014 & Eyngor et al., 2014 \\
\hline
\end{tabular}

*Year virus discovered and characterized.

\section{Viral Diseases of Crustaceans}

Apart from fish farming, shrimp farming is one of the rapidly expanding aquaculture industries whose expansion has brought with it a corresponding increase in the number of novel pathogenic viruses being discovered. Similar to observations in fish, Table 2 shows that the year when the first clinical case was identified in shrimp and the year when the etiological agent was identified, depicting long intervals allowing the diseases to reach epidemic levels before the causative agents were identified. For example, mortality due to Taura syndrome (TS) reached high epidemic proportions spreading from the Taura river in Ecuador, where the disease was first reported (Jimenez, 1992), expanding to Peru, Colombia, Brazil, Honduras, and Hawaii. It spread to Asia where it infected different shrimp species before the virus was identified (Walker and Winton, 2010). The cause was initially attributed to fungicide toxicity (Lightner et al., 1994) and the subsequent identification of Taura syndrome virus (TSV) as the etiological agent of the disease led to development of molecular diagnostic tools that paved way to breeding and cultivation of specific pathogen free (SPF) stocks to ensure that all stocks used in shrimp farming were free of the disease (OIE, 2016). Similarly, white spot syndrome virus (WSSV), shrimp infectious myonecrosis virus (IMNV), Penaeus vannamei nodavirus (PvNV) and several other shrimp viral diseases reached high epidemic levels before their etiological agents were identified and characterized (Lotz, 1997; Arcier et al., 1999; Tang and Lightner, 1999; Yang et al., 2001; van Hulten et al., 2001). Identification of the causative agents for these diseases paved way to developing diagnostic tools that are currently used for the screening of breeding stocks to ensure that only SPF stocks are used for shrimp production (Lotz, 1997; Arcier et al., 1999; Tang and Lightner, 1999; van Hulten et al., 2001; Yang et al., 2001; OIE, 2016). Hence, it is important that proactive diagnostic tools able to timely identify novel pathogenic viruses are devised in order to expedite the process of developing effective disease control strategies against emerging viral disease in aquaculture.

\section{Marine Mammal Viral Diseases}

Although calicivirus infections date as far back as 1932 when pigs that were fed raw garbage in Los Angeles in California resulted in an outbreak that caused high mortality in the infected pigs, the disease in marine mammals was first reported in 1972 from rectal swabs of Californian sea lions (Zalophus californianus) that had just aborted on San Miguel Island (Smith and Boyt, 1990). The causative agent was characterized and named San Miguel sea lion virus type I (SMSV-1). When SMSV-1 was administered in pigs, it caused classical vesicular exanthema syndrome in pigs comparable to the 1932 outbreak (Smith et al., 1973, 1998; Smith and Boyt, 1990). By 1982, calicivirus virus infections had been isolated from 11 pinnipeds and cetaceans and the host range of infected species has continued to increase (Smith et al., 1998). Marine mammal morbilliviruses were first discovered in late 1980s following a large outbreak in which approximately 18,000 harbor seals and gray seals were found dead on Northern European coasts in 1987-1988. The etiological agent was classified as phocine distemper virus (PDV). Similar high mortalities involving thousands of animals were reported in subsequent years in different species including porpoises (Phocoena phocoena) (Kennedy et al., 1988), Phoca caspisa (Kennedy et al., 2000; Ohashi et al., 2001; Kuiken et al., 2006), Stenella coeruleoalba (Domingo et al., 1990), Tursiops truncates (Lipscomb et al., 1994a,b), and Phoca vitulina (de Swart et al., 1996), harp seals (Phoca groenlandica) (Markussen and Have, 1992). The first report of influenza virus infections in marine mammals was in 1979 when more $>500$ harbor seals were found dead on the North Eastern Coast of the USA due to H7N7 subtype infections (Lang et al., 1981; Webster et al., 1981b). In 1982-1983, an outbreak of influenza due 
TABLE 2 | Shrimp viruses discovered using traditional cell culture methods.

\begin{tabular}{|c|c|c|c|c|c|c|}
\hline \multirow[t]{2}{*}{ Virus } & \multirow[t]{2}{*}{ Virus family } & \multirow[t]{2}{*}{ Nucleic acid } & \multicolumn{2}{|c|}{ Clinical signs first reported } & \multicolumn{2}{|c|}{ Etiological virus identified and characterized } \\
\hline & & & Year* & References & Year* & References \\
\hline $\begin{array}{l}\text { Infectious hypodermal and } \\
\text { hematopoietic necrosis virus }\end{array}$ & Parvoviridae & ssDNA & 1981 & $\begin{array}{l}\text { Brock et al., 1983; Lightner } \\
\text { et al., } 2004\end{array}$ & 1984 & Lightner and Redman, 1985 \\
\hline Taura syndrome virus & Dicistroviridae & $(+)$ ssRNA & 1991 & Jimenez, 1992 & 1994 & Hasson et al., 1995 \\
\hline Yellow head disease virus & Roniviridae & $(+)$ ssRNA & 1991 & Limsuwan, 1991 & 1999 & Tang and Lightner, 1999 \\
\hline White spot syndrome virus & Nimaviridae & dsDNA & 1992 & Lotz, 1997 & 2001 & van Hulten et al., 2001; Yang et al., 2001 \\
\hline $\begin{array}{l}\text { Macrobrachium rosenbergil } \\
\text { nodavirus }\end{array}$ & Nodaviridae & $(+)$ ssRNA & 1997 & Arcier et al., 1999 & 1999 & Arcier et al., 1999 \\
\hline $\begin{array}{l}\text { Shrimp infectious } \\
\text { myonecrosis virus }\end{array}$ & Totiviridae & dsRNA & 2002 & $\begin{array}{l}\text { Lightner et al., 2004; Nunes } \\
\text { et al., } 2004\end{array}$ & 2006 & Poulos et al., 2006 \\
\hline Penaeus vannamei nodavirus & Nodaviridae & $(+) \operatorname{ssRNA}$ & 2004 & Tang et al., 2007 & 2004 & Tang et al., 2007 \\
\hline
\end{tabular}

*Year virus discovered and characterized.

to subtype H4N5 caused mortality in more than 60 harbor seals in Massachusetts coastal areas in the USA (Hinshaw et al., 1984). Since then, influenza A and B viruses have been isolated from different cetaceans and pinnipeds of which postmortem handing has been linked to zoonotic infections in humans (Webster et al., 1981a,b; Hinshaw et al., 1984, 1986).

The earliest reports of adenovirus infections in marine mammals were in the late 1970s in large numbers of sea lions that had clinical signs of hepatitis and enteritis (Britt et al., 1979; Dierauf et al., 1981; Goldstein et al., 2011). Since then, adenoviruses have been isolated from California sea lions, South African fur seals (Arctocephalus pusillus), South American sea lions (Otaria flavescens) (Inoshima et al., 2013), sei whales (Balaenoptera borealis) (Inoshima et al., 2013), bowhead whales (Balaena mysticetus) (Smith et al., 1987; Inoshima et al., 2013), beluga whale (Delphinapterus leucas), and bottlenose dolphins (T. truncates) (Rubio-Guerri et al., 2015). The first report of marine mammal herpesvirus infection was from an outbreak of several harbor seals that had acute pneumonia and hepatitis in the Netherland in 1985 (Osterhaus et al., 1985). Thereafter, herpesviruses have been isolated from several species including harbor seal (P. vitulina) (Borst et al., 1986), bottlenose dolphin (Tursiops truncatus) (Manire et al., 2006; van Elk et al., 2009), orca (Orcinus orca) (Maness et al., 2011), California sea lion (King et al., 2002; Buckles et al., 2006), and gray seals (Halichoerus grypus) (Harder et al., 1996). Other viruses shown to infect marine mammals include poxviruses that have been reported in cetaceans and pinnipeds of which some are zoonotic (Van Bressem et al., 1993; Bracht et al., 2006; Waltzek et al., 2012) and astroviruses that have been associated with diarrhea in California sea lions, Steller sea lion (Eumetopias jubatus) and bottlenose dolphin (Rivera et al., 2010). Put together, these studies further consolidate the notion that our response to viral infections in aquatic organisms has mainly been reactive given that the causative agents for these diseases were only identified after they caused massive outbreaks reaching epidemic proportions. Hence, there is need for proactive diagnostic tools for the timely identification of novel pathogens having the potential to cause disease outbreaks in order to help design effective disease control strategies.

\section{DISCOVERY OF NEW VIRUSES USING VIRAL METAGENOMICS}

Viral metagenomics has led to discovery of several new viruses in different aquatic organisms including fish, crustaceans, molluscs, turtles, and marine mammals as shown below.

\section{Novel Fish Viruses}

Recently identified pathogenic viruses of fish include the circovirus isolated from barbell fish (Barbus barbus), which causes mortality within 4-6 days after hatching (Lőrincz et al., 2011). Phylogenetic analysis of two complete genomes classified as Barbell circovirus 1 and 2, (BaCV1 and BaCV2) showed that these viruses belong to two new genetic groups within the Circoviridae family, which are distinct from previously known circoviruses (Lörincz et al., 2011). Apart from barbell fish, circoviruses have been detected in common bream (Abramis brama), asp (Aspius aspius), round goby (Neogobius melanostomus), monkey goby (Neogobius fluviatilis), and roach (Rutilus rutilus) (Tarján et al., 2014). Novel circoviruses have also been identified from the European catfish (Silurus glanis) (Lörincz et al., 2012) and European eel (Anguilla anguilla) showing clinical signs of a cauliflower-like disease (Fichtner et al., 2013). Reuter et al. (2015) identified a novel posavirus designated as Fisavirus 1 (FisaV1) from freshwater carp (Cyprinus carpio) and a novel seadornavirus resembling the mammalian Banna virus from freshwater carp (Reuter et al., 2013). In another study, Boros et al. (2011) identified a novel (+)ssRNA virus with a di-cistronic genome in carp while Mor and Phelps (Mor and Phelps, 2016b) identified a novel totivirus from Gold shiner (Notemigonus crysoleucas) baitfish using NGS. The majority of viruses shown in Table 3 have only been discovered in the last 4 years unlike viruses in Table 1, which took long to discover using traditional methods. Hence, the rate at which viruses in Table $\mathbf{1}$ were discovered compared to viruses in Table 3 supports our notion that NGS and viral metagenomics are proactive diagnostic 
TABLE 3 | Fish and shellfish viruses discovered using NSG and Metagenomics analysis.

\begin{tabular}{|c|c|c|c|c|c|c|}
\hline Virus & ABBR & Virus family & NA & Host species (Scientific name) & Year* & References \\
\hline Sea turtle tornovirus 1 & STTV1 & Papilloma & ssDNA & Florida green sea turtle & 2009 & $\mathrm{Ng}$ et al., $2009 \mathrm{a}$ \\
\hline Erythrocytic necrosis virus & ENV & Iridoviridae & dsDNA & Pacific herring (Clupea pallasii) & 2011 & Emmenegger et al., 2014 \\
\hline Piscine orthoreovirus & PRV & Reoviridae & dsRNA & Atlantic salmon (Salmo salar L.) & 2011 & Palacios et al., 2010 \\
\hline Farfantepenaeus duorarum nodavirus & FdNV & Nodaviridae & $(+)$ ssRNA & Shrimp (Farfantepenaus duirarum) & 2013 & Ng et al., 2013 \\
\hline Catfish circovirus & CfCV & Circoviridae & ssDNA & European Catfish (Silurus glanuris) & 2013 & Lőrincz et al., 2012 \\
\hline Starling circovirus & StCV & Circoviridae & ssDNA & Estuarine Mollusc (Amphibola crenata) & 2013 & Dayaram et al., 2013a \\
\hline Japanese ell endothelial cell virus & JEECV & Polyomaviridae & dsDNA & Japanese eel (Anguilla japonica) & 2013 & Mizutani et al., 2011 \\
\hline Eel picornavirus & EPV-1 & Picornavirus & $(+)$ ssRNA & European eel (Angilla anguilla) & 2013 & Fichtner et al., 2013 \\
\hline Banna virus & BALV & Reoviridae & dsRNA & Fresh water carp (Cyrpinus carpio) & 2013 & Reuter et al., 2013 \\
\hline $\begin{array}{l}\text { Gastrop-associated circular ssDNA } \\
\text { virus }\end{array}$ & GaSCV & Unknown & ssDNA & Estuarine mollusk (Amphibola crenata) & 2013 & Dayaram et al., 2013b \\
\hline Balaton virus & BALV & Reoviridae & dsRNA & Freshwater carp (Cyrpinus carpio) & 2013 & Reuter et al., 2013 \\
\hline $\begin{array}{l}\text { Shrimp hepatopancreas associated } \\
\text { circular DNA virus }\end{array}$ & CDV & Circulovirus & ssDNA & Pink shrimp (Farfantepenaus duirarum) & 2013 & Ng et al., 2013 \\
\hline Sea-star wasting disease virus & SSaDV & Parvoviridae & ssDNA & Sea stars (Pycnopodia helianthoides) & 2014 & Hewson et al., 2014 \\
\hline Carp picornavirus 1 & CPV-1 & Picornaviridae & $(+)$ ssRNA & Carp (Cyprinus carpio) & 2014 & Lange et al., 2014 \\
\hline Densoviruses & & Parvoviridae & ssDNA & Urchin (Colobocentrotus atratus), & 2014 & Gudenkauf et al., 2014 \\
\hline Penaeus monodon circovirus 1 & PmCV-1 & Circoviridae & ssDNA & Shrimp (Penaeus monodon) & 2014 & Pham et al., 2014 \\
\hline Fathead minnow picornavirus & FHMV & Picornaviridae & $(+) \operatorname{ssRNA}$ & Golden shiner (Notemigonus crysoleucas) & 2014 & Phelps et al., 2014 \\
\hline $\begin{array}{l}\text { Asterias forbesi-associated circular } \\
\text { virus }\end{array}$ & AfaCV & Circulovirus & ssDNA & Asterias forbesi & 2015 & Fahsbender et al., 2015a \\
\hline Fisavirus 1 & FisaV1 & Posavirus & $(+)$ ssRNA & Carp (Cyrpinus carpio) & 2015 & Reuter et al., 2015 \\
\hline White sucker hepatitis B virus & WSHBV & Hepadnaviridae & dsDNA & White sucker (Catostomus commersonii) & 2015 & Hahn et al., 2015 \\
\hline Golden Shiner totivirus & GSTV & Totiviridae & dsRNA & Golden Shiner (Notemigonus crysoleucas) & 2016 & Mor and Phelps, 2016b \\
\hline Piscine myocarditis like virus & PMCLV & Reoviridae & dsRNA & Golden Shiner (Notemigonus crysoleucas) & 2016 & Mor and Phelps, 2016a \\
\hline Bluegill hepadnavirus & BGHB & Hepadnaviridae & dsDNA & Bluegill (Lepomis macrochirus) & 2016 & Dill et al., 2016 \\
\hline
\end{tabular}

NA, Nucleic acid. *Year virus discovered and characterized.

methods that have significantly accelerated our ability to identify novel viruses of fish.

\section{Novel Viruses of Crustaceans}

$\mathrm{Ng}$ et al. (2013) identified two nodaviruses from the pink shrimp (Frafantepenaeus duorarum hepatopancreas), which is a commercially important farmed shrimp species. One virus clone had a $403 \mathrm{nt}$ insert encoding the RNA-dependent-RNA polymerase (RdRp) partial sequence while the other contained a $236 \mathrm{nt}$ insert encoding a capsid protein partial sequence. Phylogenetic analysis showed that the capsid sequence was $43-51 \%$ similar to the shrimp nodaviruses, Macrobrachium rosenbergii nodavirus $(\mathrm{MrNV})$ and $P$. vannamei nodavirus (PvNV), which causes white tail disease in prawns ( $M$. rosenbergii), and muscle necrosis disease in shrimp (Litopenaeus vannamei) (Table 2). Apart from FdNV, Ng et al. (2013) also identified the shrimp hepatopancreas associated circular virus (ShrimpCDV) from the digestive tract of the pink shrimp. Based on these findings, it can be concluded that viral metagenomics can be used to identify novel viral pathogens of shrimps. Once the genomic sequence of the novel virus has been determined, specific molecular biology diagnostic tools such as PCR can be designed and used for the screening of brood stock in order to ensure that only SPF stocks are used for shrimp production. In this way viral metagenomics is expected to play an important role in developing effective disease control strategies for novel viral infections of crustaceans before they cause devastating economic losses in aquaculture.

\section{Novel Viruses of Mollusks, Turtle, and Star-Fish}

Apart from fish and crustaceans, the farming of different species of mollusks, turtle, and starfish has also increased tremendously in the last few decades. Interestingly, novel viruses for these aquatic organisms have also been identified using viral metagenomics (Table 3). Ng et al. (2009a) identified a novel sea turtle tornovirus 1 (STTV1) as the cause of fibropapilloma tumors in Florida sea green turtles. Hewson et al. (2014) identified a novel Forbes sea star (Asterias forbes) virus (AFSSV) as the causative agent of a wasting disease condition linked to high mortality in the Forbes sea stars. On the other hand, Andrade et al. (2015) showed that oysters are the hotspots for Mimivirus isolations which are the largest viruses found in the world with $>1,100,000 \mathrm{bp}$ length. Overall, these findings show that viral metagenomics analysis is a powerful tool able to identify novel pathogenic viruses infecting different aquatic organisms.

\section{Novel Marine Mammal Viruses}

Captive marine mammals such as the Californian sea lions ( $Z$. californianus) and bottle-nose dolphins (Tursiops tuncatus) are 
widely used as recreation animals. And as such, these animals are kept in marine parks where they are used in circus shows and other activities because of their intelligence and easy trainability. Given their close contact with humans, it has become expedient that their disease profile is determined both for public health reasons and for the sake of providing timely healthcare when they become infected with different diseases. Recently, Ng et al. (2009b) used viral metagenomics analysis to identify a novel California sea lion anellovirus (ZcAV) having 35\% amino acid homology in the open reading frame (ORF) 1 with the feline anellovirus. In another study, Ng et al. (2011) used metagenomics analysis to identify a novel seal anellovirus (SealAV) in Pacific harbor seals (Phoca vitulina richardsii). Kluge et al. (2016) carried out a viral metagenomics survey from feces of subantarctic fur seals (Arctocephalus tropicalis) and South America fur seal (Arctocephalus australis). From the South America fur seals they identified seal anellovirus 5 (SaV5), and Troque teno salophus virus 1 (TTZV) while in the Subantarctic seal fur picornaviruses were identified namely Fur seal sakobuvirus (FSSV) having $50 \%$ amino acid identity resemblance to the Feline sakobuvirus A (FSVA). In addition, rotaviruses were identified from the subantarctic fur seals with 45-69\% amino acid homology with group $\mathrm{C}$ rotaviruses. The identification of rotaviruses from Fur seals has important public health implications given that these animals are commonly found on coastal areas of South America where they attract a lot of tourism where they could serve as a source of zoonotic infections to tourists. These findings suggest that viral metagenomics can be used to obtain disease profiles for aquatic animals as well as profiles of zoonotic pathogens found in marine mammals. Table 4 shows some of the aquatic mammalian viruses discovered using viral metagenomics and NGS. It is interesting to note that most of the viruses shown in Table 3 have only been discovered in the last 4 years further consolidating the notion that viral metagenomics is accelerating our ability to identify novel viruses infecting aquatic organisms.

\section{DIAGNOSTIC ROLE OF VIRAL METAGENOMICS IN CLINICAL TISSUES}

Viral metagenomics have been used to directly identify novel etiological agents from tissues of diseased animals showing pathological changes (Finkbeiner et al., 2008; Yongfeng et al., 2011).

\section{Identification of Etiological Agents of Single Infection}

Ng et al. (2009a,b, 2013) used lung tissues to identify the ZcAV infecting Sea lions in two separate mortality events. They $(\mathrm{Ng}$ et al., 2009b) showed that ZcAV was mainly found in the lungs and pleural-cavity and not in blood, tonsils, lymph nodes, liver, and other organs suggesting that metagenomics can be used to determine tissue tropism of novel viruses in hosts. Follow-up studies showed that the prevalence was high during outbreaks in captive sea lions (100\%) and low in reservoir wild sea lions (11\%) indicating viral metagenomics can be used to monitor the prevalence of the virus in marine animals. In follow-up studies, the virus from Sea lion was used to develop an enzyme linked immunosorbent assay (ELISA) and specific PCR (Fahsbender et al., 2015b). Apart from ZcAV, Ng et al. (2011) used infected lung tissues of Pacific harbor seals (P. vitulina richardsii) to identify SealAV. Hewson et al. (2014) used viral metagenomics to identify the Sea star-associated densovirus (SSaDV) as the causative agent of a wasting disease characterized by behavioral changes, lesions on the limbs, loss of tugor and death due to rapid degradation in infected sea-star (asteroid). They observed that increase in viral titers correlated with increase in pathology in the infected sea stars. Ng et al. (2009a) used tumors to identify STTV1 as the causative agent of fibropappillomas in Florida green sea turtles. Bodewes et al. (2015) identified Phocine herpesvirus 7 (PhHV-7) as the etiological agent of ulcerative gingivitis in phocines (Bodewes et al., 2015) while Enhydralutis papilloma virus 1 (EIPV-1) was shown to be the etiological agent of oral tumors diagnosed in Southern otters (Enhydra lutris Nereis) (Ng et al., 2015).

\section{Identification of Etiological Agents of Co-Infections}

Yang et al. (2011) have pointed out that viral metagenomics has a high chance of identifying co-infections than traditional diagnostic methods. Ng et al. (2009a) showed that STTV1 existed as a co-infection of a quasispecies of variant strains from a single fibropappilloma tumor in each infected turtle. The STTV1 variants detected by viral metagenomics were identical from the majority part of the viral genome while hypervariable regions (HVRs) were extensively divergent. Based on these findings, it can be concluded that viral metagenomics does not only serve as a diagnostic tool for identifying novel viruses, but it serves as a reliable tool for identifying coinfections of different viruses working together to cause disease as well as identification of co-infections of variant strains of the same virus existing as a quasi-species in a single infection.

\section{GENERAL DISCUSSION AND CONCLUSIONS}

In this review, we have shown that viral metagenomics is a proactive diagnostic tool able to enhance the discovery of novel pathogenic viruses in aquaculture. In terms of the discovery of novel viruses, the de novo assemblies coupled with bioinformatics annotation tools used in viral metagenomics have simplified the task of identifying different sequence segments and variable proteins (VP) that constitute the assemblage of complete viral genomes. As for viral diagnostics, it can be used to identify etiological agents of single infections, co-infections, and tissue tropism. It can also be used for disease surveillance by profiling viruses infecting in different host species and determining disease prevalence in selected host species. As for quasispecies analyses, metagenomics analysis can help identify segments of the viral genome prone to genetic diversity and the conserved segments. Hence, viral metagenomics can be used as multifaceted tool 
TABLE 4 | Marine mammalian viruses discovered using NSG and Metagenomics analysis.

\begin{tabular}{|c|c|c|c|c|c|c|}
\hline Virus & ABBR & Virus family & Nucleic acid & Host species (Scientific name) & Year* & References \\
\hline California sea lion anellovirus & ZcAV & Anellovirdae & ssDNA & Californian sea lion (Zalophus californianus) & 2009 & $\mathrm{Ng}$ et al., 2009b \\
\hline Steller sea lion reovirus & SSRV & Reoviridae & dsRNA & Steller sea lion (Eumetopias jubatus) & 2011 & Palacios et al., 2011 \\
\hline California sea lion sapovirus & CsISV & Caliciviridae & $(+)$ ssRNA & Californian sea lion (Zalophus californianus) & 2011 & Li et al., 2011 \\
\hline California sea lion sapelovirus & CsISaV & Picornaviridae & $(+)$ ssRNA & Californian sea lion (Zalophus californianus) & 2011 & Li et al., 2011 \\
\hline California sea lion astrovirus & CslAstV & Astroviridae & $(+)$ ssRNA & Californian sea lion (Zalophus californianus) & 2011 & Li et al., 2011 \\
\hline California sea lion norovirus & CsINV1170 & Caliciviridae & $(+)$ ssRNA & Californian sea lion (Zalophus californianus) & 2011 & Li et al., 2011 \\
\hline California sea lion rotavirus- 1 & CsIRV1 & Reoviridae & dsRNA & Californian sea lion (Zalophus californianus) & 2011 & Li et al., 2011 \\
\hline California sea lion bocaviruses & CsIBoV & Parvoviridae & ssDNA & Californian sea lion (Zalophus californianus) & 2011 & Li et al., 2011 \\
\hline Seal parvovirus & SealPV & Parvoviridae & ssDNA & Harbor seals (Phoca hispida) & 2013 & Bodewes et al., 2013 \\
\hline Seal allenovirus 2 & SealAV-2 & Anelloviridae & $(+)$ ssRNA & Pacific harbor seals (Phoca vitulina) & 2013 & Bodewes et al., 2013 \\
\hline Seal allenovirus 3 & SealAV-3 & Anelloviridae & $(+)$ ssRNA & Pacific harbor seals (Phoca vitulina) & 2013 & Bodewes et al., 2013 \\
\hline Dolphin rhabdovirus & DRV & Rhabdoviridae & $(-)$ ssRNA & White-beaked dolphin (Lagenorhynchus albirostris) & 2014 & Siegers et al., 2014 \\
\hline $\begin{array}{l}\text { Sea lion associated stool } \\
\text { parvovirus }\end{array}$ & Sesavirus & Parvoviridae & ssDNA & Californian sea lion (Zalophus californianus) & 2015 & Phan et al., 2015 \\
\hline Phocine herpesvirus 7 & $\mathrm{PhHV7}$ & Herpesviridae & dsDNA-RT & Seals (Phoca vitulina) & 2015 & Bodewes et al., 2015 \\
\hline Fur eal sakoburis 1 & FSSV) & Pirconaviridae & $(+)$ ssRNA & Subantractic fur seal & 2016 & Kluge et al., 2016 \\
\hline Seal anellovirus 5 & SaV-5 & Anelloviridae & $(+)$ ssRNA & Fur seal (Arctocephalus australis) & 2016 & Kluge et al., 2016 \\
\hline Troque teno salophus virus & TIZV 1 & Anelloviridae & $(+)$ ssRNA & Fur seal (Arctocephalus australis) & 2016 & Kluge et al., 2016 \\
\hline
\end{tabular}

*Year virus discovered and characterized.

for the identification of novel viruses, phylogenetic analyses, diagnosis of single and co-infection, tissue tropism, and disease surveillance. Moreover, it has been shown that metagenomics analyses can be used to study the epidemiology of viruses outside their susceptible hosts using environmental samples (Munang'andu, 2016). Despite so, viral metagenomics has some limitations that require the support of traditional diagnostic methods. For example, novel viral pathogens identified using viral metagenomics require verification, which calls for isolation of the etiological agent using cell culture, followed by virus characterization and infecting of susceptible hosts to show that the isolated virus is the causative agent of the identified disease by fulfilling the Koch's postulates (Rivers, 1937). And as pointed out by different scientists that the bulk of viruses generated by metagenomics are unculturable (Handelsman, 2004; Schloss and Handelsman, 2005), verification can be a difficult challenge in situation where virus isolation and characterization tools are not available. Although PCR has also been used for verification, Yang et al. (2011) showed lack of correlation of between viral metagenomics and PCR data in their studies, which they attributed to possible errors in annotation, errors de novo assembly, sequencing biases and low sequencing depth. These observations further consolidate the notion that verification of viral metagenomics data can be a difficult challenge.

Another important challenge faced in viral metagenomics analysis is that a large proportion of viral sequences generated using this tool remain uncharacterized mainly because they have no similarity with any known sequences in common databanks. Rosario et al. (2009) generated 70\% unknown DNA viral sequences from reclaimed water while Zhang et al. (2006) produced 91\% unknown viral sequences from human feces. In another study, Breitbart et al. (2002) generated 65\% unknown viral sequences from seawater while Rosario et al. (2009) produced 57\% unknown RNA viral sequences from reclaimed water. And as pointed out by Mokili et al. (2012), there is a general lack of appropriate bioinformatics tools for the characterization of unknown viral sequences this far. Li et al. (2016), pointed out that one of the problems associated with de novo assembly of viral sequences is that they sometimes form chimeric contigs made of artificially combined reads that are not easy to identify. Hence, the bulk of uncharacterized viral sequences, sometimes referred to as the "dark matter of metagenomics," limits our ability to identify novel pathogens using this tool given that new viruses without homologous sequences in public databases are likely not to be identified. Kim and Bae (2011) compared the linker amplified shotgut library (LASL) with the multiple displacement amplification (MDA) methods and showed that there were more dsDNA viruses amplified from the LASL than the MDA library. On the contrary, the MDA library had more ssDNA viruses than dsDNA viruses from the sample, which is in line with observations made by Roux et al. (2016) who also showed that the choice of amplification method has a bias on ssDNA and dsDNA viruses detected from the same sample. Wommack et al. (2008) showed that short reads $(<400 \mathrm{bp}$ ) tend to miss distant sequences in phylogenetic classification and that they are prone to miss BLAST homologs found in long reads, indicating that the length of the reads matter thereby posing a challenge in the choice of tools required for de novo assembly to ensure that only long reads are produced for easy of taxonomical classification of viruses.

Finally, another important challenge faced with viral metagenomics analysis is that the accuracy of the methods 
used for aligning the de novo assembled genomes have not been investigated in detail (Mokili et al., 2012). The accuracy of annotation methods for identify novel viruses using metagenomics analyses in terms of avoiding false positives and negatives is unknown (Bibby, 2013). Given that the majority of viruses infecting aquatic organisms have not been characterized and that they are not found in databanks, it is highly likely that this inaccuracy might be higher for novel viruses infecting aquatic organisms. Nevertheless, it is evident based on the synopsis put forth in this review that viral metagenomics studies have positively contributed to enhancing our ability to identify novel viruses infecting aquatic organisms. Apart from the discovery of novel pathogens, it is important to point out that viral metagenomics studies have also increased our knowledge of phage dynamics which may new applications for phage therapies

\section{REFERENCES}

Alavandi, S. V., and Poornima, M. (2012). Viral metagenomics: a tool for virus discovery and diversity in aquaculture. Indian J. Virol. 23, 88-98. doi: 10.1007/s13337-012-0075-2

Amin, A., and Trasti, J. (1988). Endomyocarditis in Atlantic salmon in Norwegian seafarms. Bull. Eur. Assoc. Fish Pathol. 8, 70-71.

Andrade, K. R., Boratto, P. P., Rodrigues, F. P., Silva, L. C., Dornas, F. P., Pilotto, M. R., et al. (2015). Oysters as hot spots for mimivirus isolation. Arch. Virol. 160, 477-482. doi: 10.1007/s00705-014-2257-2

Arcier, J.-M., Herman, F., Lightner, D. V., Redman, R. M., Mari, J., and Bonami, J.-R. (1999). A viral disease associated with mortalities in hatchery-reared postlarvae of the giant freshwater prawn Macrobrachium rosenbergii. Dis. Aquat. Organ. 38, 177-181. doi: 10.3354/dao038177

Bibby, K. (2013). Metagenomic identification of viral pathogens. Trends Biotechnol. 31, 275-279. doi: 10.1016/j.tibtech.2013.01.016

Bodewes, R., Contreras, G. J., García, A. R., Hapsari, R., van de Bildt, M. W., Kuiken, T., et al. (2015). Identification of DNA sequences that imply a novel gammaherpesvirus in seals. J. Gen. Virol. 96, 1109-1114. doi: 10.1099/vir.0.000029

Bodewes, R., Rubio García, A., Wiersma, L. C., Getu, S., Beukers, M., Schapendonk, C. M., et al. (2013). Novel B19-like parvovirus in the brain of a harbor seal. PLoS ONE 8:e79259. doi: 10.1371/journal.pone.0079259

Boros, Á., Pankovics, P., Simmonds, P., and Reuter, G. (2011). Novel positivesense, single-stranded RNA (+ssRNA) virus with di-cistronic genome from intestinal content of freshwater carp (Cyprinus carpio). PLoS ONE 6:e29145. doi: 10.1371/journal.pone.0029145

Borst, G. H., Walvoort, H. C., Reijnders, P. J., Van Der Kamp, J. S., and Osterhaus, A. D. (1986). An outbreak of a herpesvirus infection in harbor seals (Phoca vitulina). J. Wildl. Dis. 22, 1-6. doi: 10.7589/0090-3558-22.1.1

Boucher, P., Castric, J., and Laurencin, F. B. (1994). Observation of virus-like particles in rainbow trout Oncorhynchus mykiss infected with sleeping disease virulent material. Bull. Eur. Assoc. Fish Pathol. 14, 215-216.

Bracht, A. J., Brudek, R. L., Ewing, R. Y., Manire, C. A., Burek, K. A., Rosa, C., et al. (2006). Genetic identification of novel poxviruses of cetaceans and pinnipeds. Arch. Virol. 151, 423-438. doi: 10.1007/s00705-005-0679-6

Breitbart, M., Salamon, P., Andresen, B., Mahaffy, J. M., Segall, A. M., Mead, D., et al. (2002). Genomic analysis of uncultured marine viral communities. Proc. Natl. Acad. Sci. U.S.A. 99, 14250-14255. doi: 10.1073/pnas.202488399

Britt, J. O. Jr., Nagy, A. Z., and Howard, E. B. (1979). Acute viral hepatitis in California sea lions. J. Am. Vet. Med. Assoc. 175:921.

Brock, J., Lightner, D., and Bell, T. (1983). “A review of four virus (BP, MBV, BMN and IHHNV) diseases of penaeid shrimp with particular reference to clinical significance, diagnosis and control in shrimp aquaculture," in Proceedings of the 71st International. Council for the Exploration of the Sea, CM (Geneva), 1-18.

Buckles, E., Lowenstine, L. J., Funke, C., Vittore, R., Wong, H.-N., St. Leger, J., et al. (2006). Otarine herpesvirus-1, not papillomavirus, is associated with endemic
(Reyes et al., 2012) suggesting that "viruses are not only demons, but could also serve as angels."

\section{AUTHOR CONTRIBUTIONS}

All authors listed participated have made substantial, direct and intellectual contribution and approved publication of the manuscript.

\section{ACKNOWLEDGMENTS}

This study was supported in part by the TRAHESA project, which is the Capacity building for training and research in aquatic and environmental health in Eastern and Southern Africa, funded by the Norwegian Development Agency, Project No. TAN/13/0027. tumours in California sea lions (Zalophus californianus). J. Comp. Pathol. 135, 183-189. doi: 10.1016/j.jcpa.2006.06.007

Castric, J., Baudin Laurencin, F., Bremont, M., Jeffroy, J., Ven, A., and 1., Bearzotti, M. (1997). Isolation of the virus responsible for sleeping disease in experimentally infected rainbow trout (Oncorhynchus mykiss). Bull. Eur. Assoc. Fish Pathol. 17, 27-30.

Dannevig, B. H., Falk, K., and Namork, E. (1995). Isolation of the causal virus of infectious salmon anaemia (ISA) in a long-term cell line from Atlantic salmon head kidney. J. Gen. Virol. 76(Pt 6), 1353-1359. doi: 10.1099/0022-1317-76-6-1353

Dayaram, A., Goldstien, S., Zawar-Reza, P., Gomez, C., Harding, J. S., and Varsani, A. (2013a). Identification of starling circovirus in an estuarine mollusc (Amphibola crenata) in New Zealand using metagenomic approaches. Genome Announc. 1:e00278-13. doi: 10.1128/genomea.00278-13

Dayaram, A., Goldstien, S., Zawar-Reza, P., Gomez, C., Harding, J. S., and Varsani, A. (2013b). Novel ssDNA virus recovered from estuarine Mollusc (Amphibola crenata) whose replication associated protein (Rep) shares similarities with Rep-like sequences of bacterial origin. J. Gen. Virol. 94, 1104-1110. doi: 10.1099/vir.0.050088-0

de Swart, R. L., Ross, P. S., Vos, J. G., and Osterhaus, A. D. (1996). Impaired immunity in harbour seals (Phoca vitulina) exposed to bioaccumulated environmental contaminants: review of a long-term feeding study. Environ. Health Perspect. 104:823. doi: 10.1289/ehp.96104s4823

Dierauf, L., Lowenstine, L. J., and Jerome, C. (1981). Viral hepatitis (adenovirus) in a California sea lion. J. Am. Vet. Med. Assoc. 179, 1194-1197.

Dikkeboom, A. L., Radi, C., Toohey-Kurth, K., Marcquenski, S., Engel, M., Goodwin, A. E., et al. (2004). First report of spring viremia of carp virus (SVCV) in wild common carp in North America. J. Aquat. Anim. Health 16, 169-178. doi: 10.1577/H03-064.1

Dill, J. A., Camus, A. C., Leary, J. H., Di Giallonardo, F., Holmes, E. C., and Ng, T. F. F. (2016). Distinct viral lineages from fish and amphibians reveal the complex evolutionary history of hepadnaviruses. J. Virol. 90, 7920-7933. doi: 10.1128/JVI.00832-16

Domingo, M., Ferrer, L., Pumarola, M., Marco, A., Plana, J., Kennedy, S., et al. (1990). Morbillivirus in dolphins. Nature 348:21. doi: 10.1038/348021a0

Edwards, R. A., and Rohwer, F. (2005). Viral metagenomics. Nat. Rev. Microbiol. 3, 504-510. doi: 10.1038/nrmicro1163

Emmenegger, E. J., Glenn, J. A., Winton, J. R., Batts, W. N., Gregg, J. L., and Hershberger, P. K. (2014). Molecular identification of erythrocytic necrosis virus (ENV) from the blood of Pacific herring (Clupea pallasii). Vet. Microbiol. 174, 16-26. doi: 10.1016/j.vetmic.2014.08.028

Eyngor, M., Zamostiano, R., Tsofack, J. E., Berkowitz, A., Bercovier, H., Tinman, S., et al. (2014). Identification of a novel RNA virus lethal to tilapia. J. Clin. Microbiol. 52, 4137-4146. doi: 10.1128/JCM.00827-14

Fahsbender, E., Hewson, I., Rosario, K., Tuttle, A. D., Varsani, A., and Breitbart, M. (2015a). Discovery of a novel circular DNA virus in the Forbes sea star, Asterias forbesi. Arch. Virol. 160, 2349-2351. doi: 10.1007/s00705-015-2503-2 
Fahsbender, E., Rosario, K., Cannon, J. P., Gulland, F., Dishaw, L. J., and Breitbart, M. (2015b). Development of a serological assay for the sea lion (Zalophus californianus) anellovirus, ZcAV. Sci. Rep. 5:9637. doi: 10.1038/srep09637

Fichtner, D., Philipps, A., Groth, M., Schmidt-Posthaus, H., Granzow, H., Dauber, M., et al. (2013). Characterization of a novel picornavirus isolate from a diseased European eel (Anguilla anguilla). J. Virol. 87, 10895-10899. doi: 10.1128/JVI.01094-13

Finkbeiner, S. R., Allred, A. F., Tarr, P. I., Klein, E. J., Kirkwood, C. D., and Wang, D. (2008). Metagenomic analysis of human diarrhea: viral detection and discovery. PLoS Pathog. 4:e1000011. doi: 10.1371/journal.ppat.1000011

Fuhrman, J. A. (1999). Marine viruses and their biogeochemical and ecological effects. Nature 399, 541-548. doi: 10.1038/21119

Gao, S. J., and Moore, P. S. (1996). Molecular approaches to the identification of unculturable infectious agents. Emerging Infect. Dis. 2, 159-167. doi: 10.3201/eid0203.960301

Glazebrook, J., Heasman, M., and Beer, S. (1990). Picorna-like viral particles associated with mass mortalities in larval barramundi, Lates calcarifer Bloch. J. Fish Dis. 13, 245-249. doi: 10.1111/j.1365-2761.1990.tb00780.x

Goldstein, T., Colegrove, K. M., Hanson, M., and Gulland, F. M. (2011). Isolation of a novel adenovirus from California sea lions Zalophus californianus. Dis. Aquat. Organ. 94, 243-248. doi: 10.3354/dao02321

Gomez-Casado, E., Estepa, A., and Coll, J. (2011). A comparative review on European-farmed finfish RNA viruses and their vaccines. Vaccine 29, 2657-2671. doi: 10.1016/j.vaccine.2011.01.097

Gross, E. L., Leys, E. J., Gasparovich, S. R., Firestone, N. D., Schwartzbaum, J. A., Janies, D. A., et al. (2010). Bacterial 16S sequence analysis of severe caries in young permanent teeth. J. Clin. Microbiol. 48, 4121-4128. doi: 10.1128/JCM.01232-10

Gudenkauf, B. M., Eaglesham, J. B., Aragundi, W. M., and Hewson, I. (2014). Discovery of urchin-associated densoviruses (family Parvoviridae) in coastal waters of the Big Island, Hawaii. J. Gen. Virol. 95, 652-658. doi: 10.1099/vir.0.060780-0

Hahn, C. M., Iwanowicz, L. R., Cornman, R. S., Conway, C. M., Winton, J. R., and Blazer, V. S. (2015). Characterization of a novel hepadnavirus in the White Sucker (Catostomus commersonii) from the Great Lakes Region of the United States. J. Virol. 89, 11801-11811. doi: 10.1128/JVI.01278-15

Handelsman, J. (2004). Metagenomics: application of genomics to uncultured microorganisms. Microbiol. Mol. Biol. Rev. 68, 669-685. doi: 10.1128/MMBR.68.4.669-685.2004

Handelsman, J., Rondon, M. R., Brady, S. F., Clardy, J., and Goodman, R. M. (1998). Molecular biological access to the chemistry of unknown soil microbes: a new frontier for natural products. Chem. Biol. 5, R245-R249. doi: 10.1016/S1074-5521(98)90108-9

Harder, T. C., Harder, M., Vos, H., Kulonen, K., Kennedy-Stoskopf, S., Liess, B., et al. (1996). Characterization of phocid herpesvirus-1 and-2 as putative alphaand gammaherpesviruses of North American and European pinnipeds. J. Gen. Virol. 77, 27-35. doi: 10.1099/0022-1317-77-1-27

Hasson, K., Lightner, D. V., Poulos, B., Redman, R., White, B., Brock, J., et al. (1995). Taura syndrome in Penaeus vannamei: demonstration of a viral etiology. Dis. Aquat. Organ. 23, 115-126. doi: 10.3354/dao023115

Haugland, O., Mikalsen, A. B., Nilsen, P., Lindmo, K., Thu, B. J., Eliassen, T. M., et al. (2011). Cardiomyopathy syndrome of atlantic salmon (Salmo salar L.) is caused by a double-stranded RNA virus of the Totiviridae family. J. Virol. 85, 5275-5286. doi: 10.1128/JVI.02154-10

Hewson, I., Button, J. B., Gudenkauf, B. M., Miner, B., Newton, A. L., Gaydos, J. K., et al. (2014). Densovirus associated with sea-star wasting disease and mass mortality. Proc. Natl. Acad. Sci. U.S.A. 111, 17278-17283. doi: $10.1073 /$ pnas.1416625111

Hinshaw, V. S., Bean, W. J., Geraci, J., Fiorelli, P., Early, G., and Webster, R. G. (1986). Characterization of two influenza A viruses from a pilot whale. J. Virol. $58,655-656$.

Hinshaw, V. S., Bean, W. J., Webster, R. G., Rehg, J. E., Fiorelli, P., Early, G., et al. (1984). Are seals frequently infected with avian influenza viruses? J. Virol. 51, 863-865.

Inoshima, Y., Murakami, T., Ishiguro, N., Hasegawa, K., and Kasamatsu, M. (2013). An outbreak of lethal adenovirus infection among different otariid species. Vet. Microbiol. 165, 455-459. doi: 10.1016/j.vetmic.2013. 04.013
Jensen, M. H. (1965). Research on the virus of egtvet disease. Ann. N. Y. Acad. Sci. 126:7.

Jimenez, R. (1992). "Syndrome de taura (Resumen)," in Acuacultura del Ecuador (Guayaquil: Camara Nacional de Acuacultura), 17.

Kennedy, S., Kuiken, T., Jepson, P. D., Deaville, R., Forsyth, M., Barrett, T., et al. (2000). Mass die-Off of Caspian seals caused by canine distemper virus. Emerging Infect. Dis. 6:637. doi: 10.3201/eid0606.000613

Kennedy, S., Smyth, J. A., Cush, P. F., McCullough, S. J., Allan, G. M., and McQuaid, S. (1988). Viral distemper now found in porpoises. Nature 336:21. doi: 10.1038/336021a0

Kim, K.-H., and Bae, J.-W. (2011). Amplification methods bias metagenomic libraries of uncultured single-stranded and double-stranded DNA viruses. Appl. Environ. Microbiol. 77, 7663-7668. doi: 10.1128/AEM.00289-11

Kimura, T., Yoshimizu, M., and Gorie, S. (1986). A new rhabdovirus isolated in Japan from cultured hirame (Japanese flounder) Paralichthys olivaceus and ayu Plecoglossus altivelis. Dis. Aquat. Organ. 1, 209-217. doi: 10.3354/dao001209

King, D. P., Hure, M. C., Goldstein, T., Aldridge, B. M., Gulland, F. M., Saliki, J. T., et al. (2002). Otarine herpesvirus-1: a novel gammaherpesvirus associated with urogenital carcinoma in California sea lions (Zalophus californianus). Vet. Microbiol. 86, 131-137. doi: 10.1016/S0378-1135(01)00497-7

Kluge, M., Campos, F. S., Tavares, M., de Amorim, D. B., Valdez, F. P., Giongo, A., et al. (2016). Metagenomic survey of viral diversity obtained from feces of subantarctic and south american fur seals. PLOS ONE 11:e0151921. doi: 10.1371/journal.pone.0151921

Kongtorp, R., Kjerstad, A., Taksdal, T., Guttvik, A., and Falk, K. (2004a). Heart and skeletal muscle inflammation in Atlantic salmon, Salmo salar L.: a new infectious disease. J. Fish Dis. 27, 351-358. doi: 10.1111/j.1365-2761.2004.00549.x

Kongtorp, R., Taksdal, T., and Lyngøy, A. (2004b). Pathology of heart and skeletal muscle inflammation (HSMI) in farmed Atlantic salmon Salmo salar. Dis. Aquat. Organ. 59, 217-224. doi: 10.3354/dao059217

Kuiken, T., Kennedy, S., Barrett, T., Van de Bildt, M., Borgsteede, F., Brew, S., et al. (2006). The 2000 canine distemper epidemic in Caspian seals (Phoca caspica): pathology and analysis of contributory factors. Vet. Pathol. Online 43, 321-338. doi: 10.1354/vp.43-3-321

Lang, G., Gagnon, A., and Geraci, J. (1981). Isolation of an influenza A virus from seals. Arch. Virol. 68, 189-195. doi: 10.1007/BF01314571

Langdon, J., Humphrey, J., Williams, L., Hyatt, A., and Westbury, H. (1986). First virus isolation from Australian fish: an iridovirus-like pathogen from redfin perch, Perca fluviatilis L. J. Fish Dis. 9, 263-268. doi: 10.1111/j.1365-2761.1986.tb01011.x

Lange, J., Groth, M., Fichtner, D., Granzow, H., Keller, B., Walther, M., et al. (2014). Virus isolate from carp: genetic characterization reveals a novel picornavirus with two aphthovirus 2A-like sequences. J. Gen. Virol. 95, 80-90. doi: 10.1099/vir.0.058172-0

Leland, D. S., and Ginocchio, C. C. (2007). Role of cell culture for virus detection in the age of technology. Clin. Microbiol. Rev. 20, 49-78. doi: 10.1128/CMR.00002-06

Li, L., Shan, T., Wang, C., Côté, C., Kolman, J., Onions, D., et al. (2011). The fecal viral flora of California sea lions. J. Virol. 85, 9909-9917. doi: 10.1128/JVI.05026-11

Li, Y., Wang, H., Nie, K., Zhang, C., Zhang, Y., Wang, J., et al. (2016). VIP: an integrated pipeline for metagenomics of virus identification and discovery. Sci. Rep. 6:23774. doi: 10.1038/srep23774

Lightner, D. V., and Redman, R. (1985). A parvo-like virus disease of penaeid shrimp. J. Invertebr. Pathol. 45, 47-53. doi: 10.1016/0022-2011(85)90048-5

Lightner, D. V., Jones, L. S., and Ware, G. W. (1994). Proceedings of Taura Syndrome Workshop: Executive Summary; Submitted Reports, and Transcribed Notes (Tucson, AZ: University of Arizona).

Lightner, D. V., Pantoja, C. R., Poulos, B. T., Tang, K. F. J., Redman, R. M., Andreas, T., et al. (2004). "Infectious myonecrosis (IMN): a new virus disease of Litopenaeus vannamei," in Book of Abstracts. World Aquaculture 2004, Honolulu, HI; Baton Rouge, LA: World Aquaculture Society.

Limsuwan, C. (1991). Handbook for Cultivation of Black Tiger Prawns. Bangkok: Tansetakit Co. Ltd.

Lipscomb, T. P., Kennedy, S., Moffett, D., and Ford, B. K. (1994a). Morbilliviral disease in an Atlantic bottlenose dolphin (Tursiops truncatus) from the Gulf of Mexico. J. Wildl. Dis. 30, 572-576. doi: 10.7589/0090-3558-30.4.572 
Lipscomb, T. P., Schulman, F. Y., Moffett, D., and Kennedy, S. (1994b). Morbilliviral disease in Atlantic bottlenose dolphins (Tursiops truncatus) from the 1987-1988 epizootic. J. Wildl. Dis. 30, 567-571. doi: 10.7589/0090-3558-30.4.567

Lőrincz, M., Cságola, A., Farkas, S. L., Székely, C., and Tuboly, T. (2011). First detection and analysis of a fish circovirus. J. Gen. Virol. 92, 1817-1821. doi: 10.1099/vir.0.031344-0

Lőrincz, M., Dán, Á., Láng, M., Csaba, G., Tóth, Á. G., Székely, C., et al. (2012). Novel circovirus in European catfish (Silurus glanis). Arch. Virol. 157, 1173-1176. doi: 10.1007/s00705-012-1291-1

Lotz, J. (1997). Viruses, biosecurity and specific pathogen-free stocks in shrimp aquaculture. World J. Microbiol. Biotechnol. 13, 405-413. doi: 10.1023/A:1018572132529

Løvoll, M., Wiik-Nielsen, J., Grove, S., Wiik-Nielsen, C. R., Kristoffersen, A. B., Faller, R., et al. (2010). A novel totivirus and piscine reovirus (PRV) in Atlantic salmon (Salmo salar) with cardiomyopathy syndrome (CMS). Virol. J. 7:309. doi: 10.1186/1743-422X-7-309

MacKinnon, M. (1987). "Rearing and growth of larval and juvenile barramundi (Lates calcarifer)" in Queensland Management of Wild and Cultured Bass/Barramundi, 148-153.

Maness, H. T., Nollens, H. H., Jensen, E. D., Goldstein, T., LaMere, S., Childress, A., et al. (2011). Phylogenetic analysis of marine mammal herpesviruses. Vet. Microbiol. 149, 23-29. doi: 10.1016/j.vetmic.2010.09.035

Manire, C. A., Smolarek, K. A., Romero, C. H., Kinsel, M. J., Clauss, T. M., and Byrd, L. (2006). Proliferative dermatitis associated with a novel alphaherpesvirus in an Atlantic bottlenose dolphin (Tursiops truncatus). J. Zoo Wildlife Med. 37, 174-181. doi: 10.1638/05-006.1

Markussen, N. H., and Have, P. (1992). Phocine distemper virus infection in harp seals (Phoca groenlandica). Mar. Mamm. Sci. 8, 19-26. doi: $10.1111 /$ j.1748-7692.1992.tb00121.x

Martínez-Porchas, M., and Vargas-Albores, F. (2015). Microbial metagenomics in aquaculture: a potential tool for a deeper insight into the activity. Rev. Aquacult. 7, 1-15. doi: 10.1111/raq.12102

McGonigle, R. (1941). Acute catarrhal enteritis of salmonid fingerlings. Trans. Am. Fish. Soc. 70, 7. doi: 2.0.co;2]10.1577/1548-8659(1940)70[297:aceosf]2.0.co;2

Mizutani, T., Sayama, Y., Nakanishi, A., Ochiai, H., Sakai, K., Wakabayashi, K., et al. (2011). Novel DNA virus isolated from samples showing endothelial cell necrosis in the Japanese eel, Anguilla japonica. Virology 412, 179-187. doi: 10.1016/j.virol.2010.12.057

Mjaaland, S., Rimstad, E., Falk, K., and Dannevig, B. H. (1997). Genomic characterization of the virus causing infectious salmon anemia in Atlantic salmon (Salmo salar L.): an orthomyxo-like virus in a teleost. J. Virol. 71, 7681-7686.

Mokili, J. L., Rohwer, F., and Dutilh, B. E. (2012). Metagenomics and future perspectives in virus discovery. Curr. Opin. Virol. 2, 63-77. doi: 10.1016/j.coviro.2011.12.004

Mor, S. K., and Phelps, N. B. (2016a). Detection and molecular characterization of a novel piscine-myocarditis-like virus from baitfish in the USA. Arch. Virol. 161, 1925-1931. doi: 10.1007/s00705-016-2873-0

Mor, S. K., and Phelps, N. B. (2016b). Molecular detection of a novel totivirus from golden shiner (Notemigonus crysoleucas) baitfish in the USA. Arch. Virol. 161, 2227-2234. doi: 10.1007/s00705-016-2906-8

Mori, K., Nakai, T., Muroga, K., Arimoto, M., Mushiake, K., and Furusawa, I. (1992). Properties of a new virus belonging to Nodaviridae found in larval striped jack (Pseudocaranx dentex) with nervous necrosis. Virology 187, 368-371. doi: 10.1016/0042-6822(92)90329-N

Munang'andu, H. M. (2016). Environmental viral metagenomics analysis in aquaculture: applications in epidemiology and disease control. Front Microbiol. 7:1986. doi: $10.3389 /$ fmicb.2016.01986

Munang'andu, H. M., and Evensen, Ø. (2015). A review of intra-and extracellular antigen delivery systems for virus vaccines of finfish. J. Immunol. Res. 2015:960859. doi: 10.1155/2015/960859

Munang'andu, H. M., Mutoloki, S., and Evensen, Ø. (2014a). Acquired immunity and vaccination against infectious pancreatic necrosis virus of salmon. Dev. Comp. Immunol. 43, 184-196. doi: 10.1016/j.dci.2013.08.008

Munang'andu, H. M., Mutoloki, S., and Evensen, Ø. (2014b). "Non-replicating Vaccines," in Fish Vaccination, eds R. Gudding, A. Lillehaug, and $\varnothing$. Evensen. (Oxford, UK: Wiley Blackwell), 22-32. doi: 10.1002/9781118806913.ch3
Munday, B., Kwang, J., and Moody, N. (2002). Betanodavirus infections of teleost fish: a review. J. Fish Dis. 25, 127-142. doi: 10.1046/j.1365-2761.2002.00350.x

Munro, A., Ellis, A., McVicar, A., McLay, H. A., and Needham, E. (1984). An exocrine pancreas disease of farmed Atlantic salmon in Scotland. Helgolander Meeresuntersuchungen 37, 571-586.

Ng, T. F., Alavandi, S., Varsani, A., Burghart, S., and Breitbart, M. (2013). Metagenomic identification of a nodavirus and a circular ssDNA virus in semipurified viral nucleic acids from the hepatopancreas of healthy Farfantepenaeus duorarum shrimp. Dis. Aquat. Organ. 105, 237-242. doi: 10.3354/dao 02628

Ng, T. F., Manire, C., Borrowman, K., Langer, T., Ehrhart, L., and Breitbart, M. (2009a). Discovery of a novel single-stranded DNA virus from a sea turtle fibropapilloma by using viral metagenomics. J. Virol. 83, 2500-2509. doi: 10.1128/JVI.01946-08

Ng, T. F., Miller, M. A., Kondov, N. O., Dodd, E. M., Batac, F., Manzer, M., et al. (2015). Oral papillomatosis caused by Enhydra lutris papillomavirus 1 (ElPV-1) in southern sea otters (Enhydra lutris nereis) in California, USA. J. Wildl. Dis. 51, 446-453. doi: 10.7589/2014-06-152

Ng, T. F., Suedmeyer, W. K., Wheeler, E., Gulland, F., and Breitbart, M. (2009b). Novel anellovirus discovered from a mortality event of captive California sea lions. J. Gen. Virol. 90, 1256-1261. doi: 10.1099/vir.0.008987-0

Ng, T. F., Wheeler, E., Greig, D., Waltzek, T. B., Gulland, F., and Breitbart, M. (2011). Metagenomic identification of a novel anellovirus in Pacific harbor seal (Phoca vitulina richardsii) lung samples and its detection in samples from multiple years. J. Gen. Virol. 92, 1318-1323. doi: 10.1099/vir.0.029678-0

Nunes, A. J., Martins, P. C. C., and Gesteira, T. C. V. (2004). Carcinicultura ameaçada. Rev. Panoram. Aquic. 83, 37-51.

Office International des Epizooties (OIE) (2016). Taura syndrome. Manual of Diagnostic Tests for Aquatic Animals (Paris), 18.

Ohashi, K., Miyazaki, N., Tanabe, S., Nakata, H., Miura, R., Fujita, K., et al. (2001). Seroepidemiological survey of distemper virus infection in the Caspian Sea and in Lake Baikal. Vet. Microbiol. 82, 203-210. doi: 10.1016/S0378-1135(01)00371-6

Osterhaus, A. D., Yang, H., Spijkers, H. E., Groen, J., Teppema, J. S., and van Steenis, G. (1985). The isolation and partial characterization of a highly pathogenic herpesvirus from the harbor seal (Phoca vitulina). Arch. Virol. 86, 239-251. doi: 10.1007/BF01309828

Palacios, G., Lovoll, M., Tengs, T., Hornig, M., Hutchison, S., Hui, J., et al. (2010). Heart and skeletal muscle inflammation of farmed salmon is associated with infection with a novel reovirus. PLOS ONE 5:e11487. doi: 10.1371 /journal.pone.0011487

Palacios, G., Wellehan J. F. Jr., Raverty, S., Bussetti, A. V., Hui, J., Savji, N., et al. (2011). Discovery of an orthoreovirus in the aborted fetus of a Steller sea lion (Eumetopias jubatus). J. Gen. Virol. 92, 2558-2565. doi: 10.1099/vir.0.03 2649-0

Pham, H. T., Yu, Q., Boisvert, M., Van, H. T., Bergoin, M., and Tijssen, P. (2014). A circo-like virus isolated from Penaeus monodon shrimps. Genome Announc. 2, e01172-e01113. doi: 10.1128/genomeA.01172-13

Phan, T. G., Gulland, F., Simeone, C., Deng, X., and Delwart, E. (2015). Sesavirus: prototype of a new parvovirus genus in feces of a sea lion. Virus Genes 50 , 134-136. doi: 10.1007/s11262-014-1123-3

Phelps, N. B., Mor, S. K., Armien, A. G., Batts, W., Goodwin, A. E., Hopper, L., et al. (2014). Isolation and molecular characterization of a novel picornavirus from baitfish in the USA. PLoS ONE 9:e87593. doi: 10.1371/journal.pone. 0087593

Poulos, B. T., Tang, K. F., Pantoja, C. R., Bonami, J. R., and Lightner, D. V. (2006). Purification and characterization of infectious myonecrosis virus of penaeid shrimp. J. Gen. Virol. 87, 987-996. doi: 10.1099/vir.0.81127-0

Reuter, G., Boros, A., Delwart, E., and Pankovics, P. (2013). Novel seadornavirus (family Reoviridae) related to Banna virus in Europe. Arch. Virol. 158, 2163-2167. doi: 10.1007/s00705-013-1712-9

Reuter, G., Pankovics, P., Delwart, E., and Boros, A. (2015). A novel posavirusrelated single-stranded RNA virus from fish (Cyprinus carpio). Arch. Virol. 160, 565-568. doi: 10.1007/s00705-014-2304-z

Reyes, A., Semenkovich, N. P., Whiteson, K., Rohwer, F., and Gordon, J. I. (2012). Going viral: next-generation sequencing applied to phage populations in the human gut. Nat. Rev. Microbiol. 10, 607-617. doi: 10.1038/nrmicr o2853 
Riesenfeld, C. S., Schloss, P. D., and Handelsman, J. (2004). Metagenomics: genomic analysis of microbial communities. Annu. Rev. Genet. 38, 525-552. doi: 10.1146/annurev.genet.38.072902.091216

Rivera, R., Nollens, H. H., Venn-Watson, S., Gulland, F. M., and Wellehan J. F. $\mathrm{Jr},(2010)$. Characterization of phylogenetically diverse astroviruses of marine mammals. J. Gen. Virol. 91, 166-173. doi: 10.1099/vir.0.015222-0

Rivers, T. M. (1937). Viruses and Koch's postulates. J. Bacteriol. 33:1.

Rosario, K., Nilsson, C., Lim, Y. W., Ruan, Y., and Breitbart, M. (2009). Metagenomic analysis of viruses in reclaimed water. Environ. Microbiol. 11, 2806-2820. doi: 10.1111/j.1462-2920.2009.01964.x

Roux, S., Solonenko, N. E., Dang, V. T., Poulos, B. T., Schwenck, S. M., Goldsmith, D. B., et al. (2016). Towards quantitative viromics for both double-stranded and single-stranded DNA viruses. PeerJ 4:e2777. doi: 10.7717/peerj.2777

Rubio-Guerri, C., García-Párraga, D., Nieto-Pelegrín, E., Melero, M., Álvaro, T., Valls, M., et al. (2015). Novel adenovirus detected in captive bottlenose dolphins (Tursiops truncatus) suffering from self-limiting gastroenteritis. BMC Vet. Res. 11:1. doi: 10.1186/s12917-015-0367-z

Rucker, R., Whipple, W., Parvin, J., and Evans, C. (1953). A contagious disease of salmon possibly of virus origin. US Fish Wildl. Serv. Fish Bull. 54, 174-175.

Schloss, P. D., and Handelsman, J. (2005). Metagenomics for studying unculturable microorganisms: cutting the Gordian knot. Genome Biol. 6:229. doi: 10.1186/gb-2005-6-8-229

Siegers, J. Y., Van De Bildt, M., van Elk, C. E., Schürch, A. C., Tordo, N., Kuiken, T., et al. (2014). Genetic relatedness of dolphin rhabdovirus with fish rhabdoviruses. Emerging Infect. Dis 20, 1081-1082. doi: 10.3201/eid2006.131880

Smith, A. W., Akers, T. G., Madin, S. H., and Vedros, N. A. (1973). San Miguel sea lion virus isolation, preliminary characterization and relationship to vesicular exanthema of swine virus. Nature 244, 108-110.

Smith, A. W., and Boyt, P. M. (1990). Caliciviruses of ocean origin: a review. J. Zoo Wildlife Med. 21, 3-23.

Smith, A. W., Skilling, D. E., Benirschke, K., Albert, T. F., and Barlough, J. E. (1987). Serology and virology of the bowhead whale (Balaena mysticetus L.). J. Wildl. Dis. 23, 92-98. doi: 10.7589/0090-3558-23.1.92

Smith, A. W., Skilling, D. E., Cherry, N., Mead, J. H., and Matson, D. O. (1998). Calicivirus emergence from ocean reservoirs: zoonotic and interspecies movements. Emerging Infect. Dis. 4:13. doi: 10.3201/eid0401.980103

Sommerset, I., Krossøy, B., Biering, E., and Frost, P. (2005). Vaccines for fish in aquaculture. Expert Rev. Vaccines 4, 89-101. doi: 10.1586/14760584.4.1.89

Streit, W. R., and Schmitz, R. A. (2004). Metagenomics-the key to the uncultured microbes. Curr. Opin. Microbiol. 7, 492-498. doi: 10.1016/j.mib.2004.08.002

Tang, K. F., and Lightner, D. V. (1999). A yellow head virus gene probe: nucleotide sequence and application for in situ hybridization. Dis. Aquat. Organ. 35, 165-173. doi: 10.3354/dao035165

Tang, K. F., Pantoja, C. R., Redman, R. M., and Lightner, D. V. (2007). Development of in situ hybridization and RT-PCR assay for the detection of a nodavirus (PvNV) that causes muscle necrosis in Penaeus vannamei. Dis. Aquat. Organ. 75, 183-190. doi: 10.3354/dao075183

Tarján, Z. L., Pénzes, J. J., Tóth, R. P., and Benko, M. (2014). First detection of circovirus-like sequences in amphibians and novel putative circoviruses in fishes. Acta Vet. Hung. 62, 134-144. doi: 10.1556/AVet.2013.061

Thorud, K., and Djupvik, H. (1988). Infectious anaemia in Atlantic salmon (Salmo salar L.). Bull. Eur. Assoc. Fish Pathol. 8, 109-111.

Van Bressem, M.-F., Van Waerebeek, K., Reyes, J. C., Dekegel, D., and Pastoret, P.P. (1993). Evidence of poxvirus in dusky dolphin (Lagenorhynchus obscurus) and Burmeister's porpoise (Phocoena spinipinnis) from coastal Peru. J. Wildl. Dis. 29, 109-113. doi: 10.7589/0090-3558-29.1.109

van Elk, C. E., van de Bildt, M. W., de Jong, A. A., Osterhaus, A. D., and Kuiken, T. (2009). Genital herpesvirus in bottlenose dolphins (Tursiops truncatus): cultivation, epidemiology, and associated pathology. J. Wildl. Dis. 45, 895-906. doi: 10.7589/0090-3558-45.4.895

van Hulten, M. C., Witteveldt, J., Peters, S., Kloosterboer, N., Tarchini, R., Fiers, M., et al. (2001). The white spot syndrome virus DNA genome sequence. Virology 286, 7-22. doi: 10.1006/viro.2001.1002
Walker, P. J., and Winton, J. R. (2010). Emerging viral diseases of fish and shrimp. Vet. Res. 41:51. doi: 10.1051/vetres/2010022

Waltzek, T., Cortés-Hinojosa, G., Wellehan, J. F. Jr., and Gray, G. C. (2012). Marine mammal zoonoses: a review of disease manifestations. Zoonoses Public Health 59, 521-535. doi: 10.1111/j.1863-2378.2012.01492.x

Wang, D., Coscoy, L., Zylberberg, M., Avila, P. C., Boushey, H. A., Ganem, D., et al. (2002). Microarray-based detection and genotyping of viral pathogens. Proc. Natl. Acad. Sci. U.S.A. 99, 15687-15692. doi: 10.1073/pnas.242579699

Webster, R. G., Geraci, J., Petursson, G., and Skirnisson, K. (1981a). Conjunctivitis in human beings caused by influenza A virus of seals. N. Engl. J. Med. 304:911. doi: 10.1056/NEJM198104093041515

Webster, R. G., Hinshaw, V. S., Bean, W. J., Van Wyke, K. L., Geraci, J. R., St. Aubin, D. J., et al. (1981b). Characterization of an influenza A virus from seals. Virology 113, 712-724. doi: 10.1016/0042-6822(81)90200-2

Wingfield, W. H., Fryer, J. L., and Pilcher, K. S. (1969). Properties of the sockeye salmon virus (Oregon strain). Exp. Biol. Med. 130, 1055-1059. doi: 10.3181/00379727-130-33719

Wolf, K., Snieszko, S. F., Unbar, C. E., and Pyle, E. (1960). Virus nature of infectious pancreatic necrosis in trout. Proc. Soc. Exp. Biol. Med. 104:4. doi: 10.3181/00379727-104-25743

Wommack, K. E., Bhavsar, J., and Ravel, J. (2008). Metagenomics: read length matters. Appl. Environ. Microbiol. 74, 1453-1463. doi: 10.1128/AEM.02181-07

$\mathrm{Xu}, \mathrm{C}$., Evensen, Ø., and Munang'andu, H. M. (2015). De novo assembly and transcriptome analysis of Atlantic salmon macrophage/dendritic-like TO cells following type I IFN treatment and Salmonid alphavirus subtype-3 infection. BMC Genomics 16:96. doi: 10.1186/s12864-015-1302-1

$\mathrm{Xu}$, C., Evensen, Ø., and Munang'andu, H. M. (2016a). A de novo transcriptome analysis shows that modulation of the JAK-STAT signaling pathway by salmonid alphavirus subtype 3 favors virus replication in macrophage/dendritic-like TO-cells. BMC Genomics 17:390. doi: 10.1186/s12864-016-2739-6

Xu, C., Evensen, Ø., and Mweemba Munang'andu, H. (2016b). De novo transcriptome analysis shows that $\mathrm{SAV}-3$ infection upregulates pattern recognition receptors of the endosomal toll-like and RIG-I-Like receptor signaling pathways in macrophage/dendritic like to-cells. Viruses 8:114. doi: 10.3390/v8040114

Yamaguchi, S., Kaji, N., Munang'andu, H., Kojima, C., Mase, M., and Tsukamoto, K. (2000). Quantification of chicken anaemia virus by competitive polymerase chain reaction. Avian Pathol. 29, 305-310. doi: 10.1080/03079450050118421

Yang, F., He, J., Lin, X., Li, Q., Pan, D., Zhang, X., et al. (2001). Complete genome sequence of the shrimp white spot bacilliform virus. J. Virol. 75, 11811-11820. doi: 10.1128/JVI.75.23.11811-11820.2001

Yang, J., Yang, F., Ren, L., Xiong, Z., Wu, Z., Dong, J., et al. (2011). Unbiased parallel detection of viral pathogens in clinical samples by use of a metagenomic approach. J. Clin. Microbiol. 49, 3463-3469. doi: 10.1128/JCM.00273-11

Yongfeng, H., Fan, Y., Jie, D., Jian, Y., Ting, Z., Lilian, S., et al. (2011). Direct pathogen detection from swab samples using a new highthroughput sequencing technology. Clin. Microbiol. Infect. 17, 241-244. doi: 10.1111/j.1469-0691.2010.03246.x

Zhang, T., Breitbart, M., Lee, W. H., Run, J. Q., Wei, C. L., Soh, S. W., et al. (2006). RNA viral community in human feces: prevalence of plant pathogenic viruses. PLoS Biol. 4:e3. doi: 10.1371/journal.pbio.0040003

Conflict of Interest Statement: The authors declare that the research was conducted in the absence of any commercial or financial relationships that could be construed as a potential conflict of interest.

Copyright (c) 2017 Munang'andu, Mugimba, Byarugaba, Mutoloki and Evensen. This is an open-access article distributed under the terms of the Creative Commons Attribution License (CC BY). The use, distribution or reproduction in other forums is permitted, provided the original author(s) or licensor are credited and that the original publication in this journal is cited, in accordance with accepted academic practice. No use, distribution or reproduction is permitted which does not comply with these terms. 